\title{
Electrical Resistivity Tomography (ERT) applied in a Uranium mine for identification of Acid Drainage Mine (AMD) zones
}

Pedro Camarero, Dr. César Augusto Moreira - Universidade Estadual Júlio de Mesquita Filho - Unesp

Copyright 2021, SBGf - Sociedade Brasileira de Geofísica.

This paper was prepared for presentation during the $17^{\text {th }}$ International Congress of the Brazilian Geophysical Society held in Rio de Janeiro, Brazil, $16-19$ August 2021.

Contents of this paper were reviewed by the Technical Committee of the $17^{\text {th }}$ International Congress of the Brazilian Geophysical Society and do not necessarily represent any position of the SBGf, its officers or members. Electronic reproduction or storage of any part of this paper for commercial purposes without the written consent of the Brazilian Geophysical Society is prohibited.

\begin{abstract}
The alkaline massif of Poços de Caldas in southern Minas Gerais, presents several occurrences of uranium and thorium. The main occurrence of the area give rise to the Osamu Utsumi Uranium Mine. During the 13 years of non-continuous operation, started in 1982, Indústrias Nucleares do Brasil - INB was the company responsible for the exploitation activities. The mine is currently in the decommissioning phase and is presenting the Degraded Area Recovery Plan (PRAD, in Portuguese). The exploitation has generated serious environmental problems, such as large amounts of chemical processing waste, rocky waste and water pollution - Acid Drainage Mine (AMD). The purpose of this work is to use the method of DC Resistivity for a hydrogeological analysis in the region of the old pit of the Osamu Utsumi mine, an area where local acid drainage occurs in the mining complex. Using the Electrical Resistivity Tomography (ERT) technique, data were acquired at strategic points in the mine pit. The arrays were dipole-dipole and Schlumberger, with $10 \mathrm{~m}$ spacing between electrodes and ERT line of $400 \mathrm{~m}$ length. The data were treated in specific software for ERT that provided distance versus depth data - 2D data. For a better understanding of the fractured aquifer system in the mine pit, a detailed structural mapping of regional and local geology was necessary. From the compilation of such field results and the genetic model of the deposit, it was possible to identify areas where there is greater water percolation through fractures in the massif and areas where there is a greater contribution of acid waters - the latter showing very low values of electrical resistivity $(<15 \Omega . \mathrm{m})$. With the delimitation and dimensioning of the acid drainage contribution zones using the DC Resistivity method, the authors hope that it will be possible to elaborate a potential map of the acid generation areas of the mine pit. Such study may be used in the future in the Osamu Utsumi mine for local remediation proposals, aiming at control or reduction of mining acid drainage. The authors hope that the methodology can also be used in other mining projects.
\end{abstract}

